\title{
Egl Nine Homolog 1
}

National Cancer Institute

\section{Source}

National Cancer Institute. Eg/Nine Homolog 1. NCI Thesaurus. Code C101545.

EgI nine homolog 1 (426 aa, $46 \mathrm{kDa}$ ) is encoded by the human EGLN1 gene. This protein plays a role in the modification of hypoxia-inducible factor alpha proteins in response to hypoxic conditions. 